\title{
Malaysian Technical Universities Conference on Engineering and Technology (MUCET 2017) \\ $6^{\text {th }}-7^{\text {th }}$ December 2017, Park Royal Hotel, Penang, Malaysia
}

\section{OPreface}

MUCET 2017 aims to provide a platform for academics and researchers to share knowledge and ideas, widen networking, present their research findings and explore any other potential benefits that might be contribute to the better future.

This conference highlights the contributions of innovative research in science, engineering and technology. Topics presented includes of Electronic and Electrical Engineering, Civil Engineering, Chemical Engineering \& Natural Resources, Mechanical \& Manufacturing Engineering, Education, Social Science \& Technology Management, Science, and Information \& Communication Technology.

Research fields of the presented papers including:

- Electronical and Electronic Engineering (EE)

- Civil Engineering (CE)

- Chemical Engineering \& Natural Resources (CHEM)

- Mechanical \& Manufacturing Engineering (MME)

- $\quad$ Education, Social Sciences \& Technology Management (ESTM)

- Information \& Communication Technology (ICT), Science (SCI) \& Mathematics (SM) 